\title{
Study on the creative thinking in critical academic English Writing
}

\author{
Mao Fanjiao \\ Changsha Medical University Huanan Changsha 410000
}

\begin{abstract}
General English academic writing compared to professional academic English differences, academic English is an important branch of English for specific purposes, different from general English test, general academic English tend to public utility, to learn the general academic English writing requires scholars critical creative thinking mode. But at present our country's education critical mode, general academic English writing in creative thinking development is not enough. Group thinking plays a leading role in breaking through the original mode of thinking, the cultivation of students' creative thinking for students in the south, has an important role in the general academic English writing, to train the students to have the correct values, innovation thinking. To meet the needs of society force on innovative talents. The current domestic experts and scholars on the value of critical thinking have a higher sense of identity, now the education mode for cultivating learning Jinxi reform. Critical thinking of students to build a platform of subject. Through reviewing the relevant treatment, innovative thinking situation and reason analysis of critical general academic writing teaching, cultivating students' critical thinking methods, draw the following conclusions.

Keywords Critical thinking General academic English writing Innovative thinking
\end{abstract}

\section{Introduction}

With Chinese joined WTO, China's economic, cultural, educational and other aspects of international standards, English for area increase, pay more attention to cultivating students' innovative thinking critical general English academic writing, 
aims to cultivate talents of language knowledge and language skills with ability training and training standards. The concept of internationalization of higher education critical general academic writing ability is concerned, students convey new ideas critically, to show the new direction of knowledge, based on the study of previous scholars' opinions, questions and reflect on their own, and through the investigation and analysis of argument or reasoning, draw their own innovative ideas. The general requirements of academic English writing is popular to understand this, consider the student's innovation ability. The critical general academic writing in English is not only the innovative thinking ability of the students attention, also It is a new requirement for teachers to cultivate students' critical thinking mode

\section{The present situation and causes of the cultivation of innovative thinking in critical general academic English Writing}

Will subvert our traditional university teaching concept to cultivate innovative thinking critical general English academic writing, for general academic English writing course of the original teaching objectives, content, mode, will reform, in order to meet the needs of students to explore the knowledge, to mobilize students' thirst for knowledge, academic value, evaluation and critical appraisal skills have milepost's role for the students' Academic English communication ability, and academic accomplishment, has important significance of cultivating the critical thinking ability. But the current status of the cultivation of creative thinking in English writing of general academic critical current education system to our country scholar.

The present situation of creative thinking in the teaching of English Writing With the advent of economic globalization, international exchanges frequently, English as an international communication tool, plays an important role in the whole process of communication, the needs of higher education institutions in China to cater to the needs of society to cultivate innovative talents to meet the social demands of English. Innovation ability of critical thinking in English Writing general academic talents with the enterprise talent recruitment standards, and the critical thinking ability of students, and is the key of international exchanges, to reduce international exchange differences. Critical thinking is to make a judgement on the authenticity of the use of appropriate evaluation criteria to determine something and that is the key to break through the original thinking mode, we can only break their original thinking the real value is put forward, the problem of innovation, ultimately to become innovative talents.

In universities will be placed on the cultivation of creative thinking at the beginning of the school academic English writing critical general students, but there is not balanced for student groups, teachers in the teaching difficulty according to the students' situation of teaching. The general academic English writing requires students to have basic English ability strong, but a lot of non 
English Majors in English, the foundation is weak, difficult to master basic English learning tips.

The author visited the relevant institutions, as well as access to relevant information found at present in Colleges and universities for students' critical general English academic writing do not pay attention, a lot of teachers for students to explain the knowledge using the traditional teaching mode, the students use "cramming" teaching. Students are required to master a large number of professional and general academic vocabulary in English writing class the amount of reading, writing training, curing the original teaching mode of students' thinking ability, although in the school test, can get high marks, but this is not test the ability of comprehensive application ability. The critical general academic English writing students in English Writing of the title, conception, layout and so on there are some problems; and because of the excessive pursuit of test scores, critical general academic English writing will show students to accumulate English Vocabulary Not enough, the basic skills of English language is not solid, grammar, spelling mistakes and so on

According to the statistical data now Chinese related institutions of higher education, most of the students' English level is usually lower than the level of thinking, lack of English thinking training, need to get the relevant educational institutions of our attention, to avoid similar mistakes.

\section{The teaching strategies of College English writing under the guidance of critical thinking}

Teachers and students should be with each other, understand the classroom efficiency to achieve the cultivation of innovative thinking modes of critical general academic English writing. The teachers in cultivating students' oral and written medicine attention to students' comprehensive language expression in general academic English writing skills, training, and development of writing subject of innovative thinking, encourage students to critical thinking training mode, remember the critical mode of innovative thinking plays an important role in the future development of students. Teachers should be guided in respect of students' thinking mode, at the same time, avoid the students general English academic writing language deviation, the implementation of effective teaching methods, cultivating students' ability of problem analysis and judgment; at the same time the students should also cooperate with teachers' teaching activities, active participation, exercise their ability of thinking, from the examination oriented education thought from the original Out, according to their ability, put forward to the teacher of his own understanding, to participate in the panel discussion, draw conclusions. Language time also as far as possible to participate in the school organization of the exhibition activities in the past (the English debate contest, English speech contest, etc.) to improve the logical ability, organize their own language strain ability, critical thinking ability, creative thinking ability. 
A lot of relevant institutions in general English academic writing courses is not reasonable, specific performance in general focus on English academic writing curriculum theory learning, training and ignore the students' practical writing skills training. Take a university's critical thinking ability to talk about the case, the students basic uneven state, first of all the word test, English listening comprehension test, excellent English writing academic lectures, intensive reading and extensive reading, report writing, let students understand the general academic English writing, critical thinking and innovation training mode of students, students in the learning process in the late, can judge the acceptance of English, logical thinking. Questions, then by consulting the relevant literature to prove their point of view. So as to improve students' innovation and critical academic English writing in general The feasibility of the mode of thinking.

Critical general academic English writing the whole process of course teaching should pay attention to the logic, the teacher as a class designer and elites, need to understand students' learning situation, unfold the curriculum design, in order to inspire students' thinking ability. commonality of lay particular stress on English writing not only professional, but based on the practice, the basic knowledge about academic English writing, from the interpretation of the background, content, purpose and the significance of using multiple perspectives such as artistic conception, let the students spontaneously, through logical explanation and analysis to make students to question the things have a sense of

enlightenment, finally.

In the academic English writing teaching, pay attention to the language learning needs with academic research. English writing is a service for academic research, the students need to break the traditional mode of thinking, value cultivate their creative thinking mode, value their critical thinking to study things, dare to break through the conventional, with a fresh perspective view.

Critical general academic English writing teachers should pay attention to the construction of students' innovative thinking mode, use of multimedia teaching resources, encourage students to use the new Angle of view, from the perspective of a language and academic problems are analyzed and compared, finally mastering language trading apply to the academic research. Students also should consciously cultivate their reverse thinking ability, questioned gm obsolete expressions in English academic writing, old research method, questioning mind in order to improve their ability. Teacher in the whole thinking process of students, to guide for students, and provide relevant general academic English writing for students reading material, research reports, etc.

Teachers in the teaching to the student should provide a teaching case of keeping the pace with The Times, the question to the student, should think ahead to self, and aimed at the problem of students in the learning process should give enough time to discuss, analysis, and then based on the students' problems, put forward their views. Pay attention to the teaching focus should be given priority to with students, must not "cramming" teaching, inhibit the development of students' thinking mode. 
Critical general academic innovative thinking training in English writing is not in the day, is a long-term process. General academic English writing courses related to learning theory knowledge, this is the student of the accumulation of vocabulary, grammar learning, expressing the logic training process, etc., is a process of learning not a dull, related colleges and universities should combine course, carry out similar to the campus game modes, such as encouraging students to take an active part in, by collecting data, planning scheme, with the temporary situation response, training students' critical general academic innovation thinking ability in English writing, let the students learning life is full of fun. Initiative to mobilize students' thinking and improve the ability of language expression has a significant effect. Students also through these activities, exercise their English writing grammar expression.

With the progress of science and technology, network course many have opened, many universities to cooperate with major learning website, launched his classroom, wisdom tree, superstar learning platform, students through learning in these classes, get some credits. The critical general academic training of creative thinking in English writing, teachers can also make full use of cyber source, through the recommendation of students online lectures, the teacher let the students according to the different writing difficult points of general academic English explanation, emphasis has its own thinking, by explaining the problems of the teacher, the learning platform put forward their own problems in virtual team communication, mutual query between team members have the common use of collection, academic information theory overturned, the common points between that team members and differences; thus the students of general academic criticism Creative thinking in English writing until training

Critical general academic English writing, teachers should pay attention to student's topic, topic, literature search, outlining the process, the teacher should act as a guide role, give students a demonstration of the evaluation, and then let the students find out the mutual evaluation, merit student, encourage students according to their positions and views, through analysis, comparison and the comprehensive evaluation of others, articles, to exercise their ability to judge others, innovative thinking mode of the two revision of creation of their own articles, package to expand, the contents of the article to delete section, spelling, grammar, cohesion, coherence, demonstration, proficiency in the use of critical thinking was evaluated.

\section{Acknowledgment}

Research project: Hunan Provincial Department of education research project, code: 16C0188 General academic English writing and Critical thinking

\section{Reference}

[1] Li Dan. Research on the cultivation of critical thinking in College English writing [J]. Journal of Shangqiu Vocational Technical College, 2014,01:77-79. 
[2] Su literary talent. Students' critical thinking in academic English teaching mode under the [J]. education teaching forum based on 2014,46:250-252.

[3] Gu Dinglan. Science and engineering academic English from the perspective of critical thinking ability cultivation of Chinese [J]. (foreign language teaching), 2016,04:129-130. [4] Xu Dandan [D]. of East China University of Science and Technology students' thinking ability. The research of general English academic writing course environment, 2015

[5] Huang Fang. The practice and exploration of cultivating critical thinking ability of college students [D]. Shanghai International Studies University, 2013

[6] Cai Jigang. The first guidance of College English teaching and learning in China with the guidance of academic English and the explanation of [J]. foreign language teaching theory and practice, 2012,04:1-9 41 